NBER WORKING PAPER SERIES

\title{
ESTIMATING THE KNOWLEDGE-CAPITAL MODEL OF THE MULTINATIONAL ENTERPRISE: COMMENT
}

\author{
Bruce A. Blonigen \\ Ronald B. Davies \\ Keith Head
}

Working Paper 8929

http://www.nber.org/papers/w8929

\author{
NATIONAL BUREAU OF ECONOMIC RESEARCH \\ 1050 Massachusetts Avenue \\ Cambridge, MA 02138 \\ May 2002
}

We would like to thank Robert Feenstra, Stephen Haynes, James Markusen, Keith Maskus, Kaoru Nabeshima, Matt Slaughter, Jim Ziliak and participants of a 2002 American Economics Association session for helpful discussions and comments. We also thank Sarah Lawson for excellent research assistance. All remaining errors or omissions are our own. The views expressed herein are those of the authors and not necessarily those of the National Bureau of Economic Research.

(C) 2002 by Bruce A. Blonigen, Ronald B. Davies and Keith Head. All rights reserved. Short sections of text, not to exceed two paragraphs, may be quoted without explicit permission provided that full credit, including (C) notice, is given to the source. 
Estimating the Knowledge-Capital Model of the Multinational Enterprise: Comment Bruce A. Blonigen, Ronald B. Davies and Keith Head

NBER Working Paper No. 8929

May 2002

JEL No. F2

\begin{abstract}
A recent American Economic Review article by David L. Carr, James R. Markusen, and Keith E. Maskus (CMM) estimates a regression specification based upon the "knowledge-capital" model of the Multinational Enterprise (MNE). The knowledge-capital model combines "horizontal" motivations for FDI -- the desire to place production close to customers and thereby avoid trade costs -- with "vertical" motivations -- the desire to carry out unskilled-labor intensive production activities in locations with relatively abundant unskilled labor. The CMM estimates pool inward and outward U.S. affiliate sales data from 1986 through 1994 and appear to support the knowledge-capital model of the MNE. We show that CMM's empirical framework mis-specifies the terms measuring differences in skilled-labor abundance, key variables that identify vertical MNE motivations. After correcting this specification error estimates no longer reject the horizontal model in favor of the knowledge-capital model. Instead, the data strongly support the predictions of the horizontal model of MNEs: affiliate activity between countries decreases as absolute differences in skill-labor abundance widen. Qualitatively identical results are also found using data that include a wider variety of parent and host countries, including data for the OECD.
\end{abstract}

Bruce A. Blonigen Department of Economics 1285 University of Oregon Eugene, OR 97403-1285 and NBER 541-346-4680 bruceb@oregon.uoregon.edu
Ronald B. Davies Department of Economics 1285 University of Oregon Eugene, OR 97403-1285 541-346-4671 rdavies@oregon.uoregon.edu 
A recent American Economic Review article by David L. Carr, James R. Markusen, and Keith E. Maskus (CMM) estimates a regression specification based upon the "knowledge-capital" model of the Multinational Enterprise (MNE). The knowledge-capital model combines "horizontal" motivations for FDI — the desire to place production close to customers and thereby avoid trade costs—with "vertical" motivations - the desire to carry out unskilled-labor intensive production activities in locations with relatively abundant unskilled labor. By way of contrast, the horizontal model, an intellectual antecedent of the knowledge-capital model, precludes the separation of knowledge-generating activities from production and therefore generates different policy implications. CMM's summary states that the results "fit well with the [knowledge-capital] theory. We hope that the model will therefore prove useful in future analysis." In this comment, we argue that rather than offering direct support for the knowledgecapital model, the data set used by CMM cannot reject the horizontal model of MNEs in favor of the knowledge-capital model.

The crux of the distinction between the knowledge capital model and the horizontal model lies with the estimate of the effect of skill differences on the level of affiliate activity in the host country. CMM find that the increases in the parent-country's relative skill endowment raise affiliate sales in the host country as long as the parent country is small. However, this effect of skill differences is decreasing in the parent-host GDP difference. They interpret these results as support for the knowledge-capital model of MNEs. We demonstrate that this finding arises because of a misspecification of the skill difference terms in their empirical framework. When corrected, we find that absolute skill differences reduce affiliate sales. This instead supports the horizontal model of the MNE and suggests that it cannot be rejected in favor of the knowledge-capital model. Our findings are robust to alternative specifications using both U.S. and OECD data.

Interest in MNEs has grown considerably in recent years for two main reasons. First, flows of foreign direct investment (FDI), the defining activity of MNEs, have grown at substantial rates over the last two decades, outstripping the rate of growth of both world output and international trade. Second, 
there has been an increasingly vocal public and academic debate on the effects of FDI, particularly with respect to labor market effects. This debate has been informed by several models of FDI, particularly those of Markusen and co-authors. ${ }^{1}$ These models are especially relevant to the debate on FDI and wages because they suggest many different motives for engaging in FDI and thus many different potential labor market effects. For example, affiliate activity in foreign countries is less likely to have a negative impact on unskilled home-country workers in a horizontal model than a knowledge-capital model.

As with the literature testing models of international trade, researchers have turned to the data to select the most appropriate model of the MNE. CMM develops an empirical framework to study the efficacy of the knowledge-capital model of MNE activity. The CMM estimates pool inward and outward U.S. affiliate sales data from 1986 through 1994 and appear to support the knowledge-capital model of the MNE. In particular, the terms they use as proxies for skilled-labor abundance differences between countries, the key variables identifying vertical MNE motivations, have the expected signs and are statistically significant. However, in related work, Markusen and Maskus $(1999,2001)$ find evidence conflicting with the knowledge capital model using the same database.

In this comment on CMM we resolve this apparent puzzle. We show that CMM's empirical framework mis-specifies the terms measuring differences in skilled-labor abundance. After correcting this specification error, the coefficient estimates no longer support the knowledge capital model. Instead, the data strongly support the predictions of the horizontal model of MNEs: affiliate activity between countries decreases as absolute differences in skill-labor abundance widen. Further, we strengthen the evidence for this result by showing that the negative relationship between FDI activity and dissimilarity in skilled-labor abundance is also found using data that include a wider variety of parent and host countries, including data for the OECD. Finally, we show exactly how the difference between CMM and Markusen and Maskus (1999;2001) follows directly from the misspecification of skill differences.

\footnotetext{
${ }^{1}$ These include James R. Markusen (1984, 1997), Ignatius J. Horstmann and Markusen $(1987,1992)$, Markusen and Anthony J. Venables (1997, 1998, 2000), and Markusen, Venables, Denise Eby-Konan, and Kevin Honglin Zhang (1996).
} 
This paper proceeds as follows. In section I, we briefly summarize the varied theories of FDI and survey the small empirical literature on the determinants of FDI. In this same section, we detail the specification error in the CMM empirical framework used to estimate the knowledge-capital model. Section II uses the CMM dataset to illustrate the stark change in coefficient estimates when we correct the specification error and shows that the same coefficient patterns appear in alternative U.S. and OECD samples of MNE activity. We do not find support in any of these data sets for rejecting the horizontal model in favor of the knowledge-capital model. Section III concludes.

\section{Recent Evidence on MNE Models: A Puzzle}

Relative to many prior empirical studies of FDI, the CMM approach represents a step forward because it bases its framework in the formal theories of the multinational firm. These theories can be divided into three rough categories: the horizontal model, the vertical model, and the knowledge-capital model. The horizontal model originates in Markusen (1984) and describes a firm with plants that engage in the same activity in multiple locations. This model posits that FDI arises from an interaction between firm-level economies of scale and trade costs. Markusen and Venables (2000) show that, in the horizontal model, dissimilarity in relative endowments reduce the activity of MNEs; thus the horizontal model predicts that absolute skill differences should be negatively related to FDI activity.

The vertical model, first formalized by Elhanan Helpman (1984), builds an incentive to locate different activities in different countries in order to take advantage of factor cost differences. One strong prediction of this model is that FDI should only flow from the skill-abundant country to the unskilled country (since a firm's nationality is identified with the location of its skill-intensive headquarters). Furthermore, when countries are identical, there is no reason to engage in FDI since there are no cost differences to exploit.

More recently, Markusen, et. al. (1996) and Markusen (1997) have developed the knowledgecapital model tested in CMM. This model integrates the horizontal and vertical models and allows for both multi-plant scale economies and exploitation of factor price differences. Since the knowledge- 
capital model is a combination of the horizontal and vertical models, it comes as no surprise that skill differences can have positive and negative effects. Specifically, a rise in skilled labor-abundance differences tends to increase FDI from the skilled country to the host (as predicted by the vertical model). This effect diminishes, however, when the unskilled host is small. Thus, while the total effect of skill differences is ambiguous due to the interactions with country size, a more-skilled large parent country should have more outbound FDI than a less-skilled or a small parent country.

A key distinction between the pure horizontal model and the knowledge-capital model is that the former assumes that headquarter services and production use factors in the same proportions. In contrast, the knowledge-capital model assumes the headquarter services use skilled-labor more intensively than all other activities. Nevertheless, there are regimes in the knowledge-capital model where multinationals of the horizontal form (plants in more than one country, headquarter services in only one) do emerge. This occurs when relative endowments are similar since this removes the factor price differences that generate the incentives for the vertical form. Thus, observing MNE activity between countries of similar factor proportions does not violate the knowledge-capital model. Nevertheless, the distinguishing feature is that a divergence in relative factor endowments reduces production of foreign affiliates in both countries in the horizontal model, but can increase it in the knowledge-capital model.

With three alternative models of MNE activity, empirical investigation naturally followed, including a set of papers by Markusen and Maskus: CMM, Markusen and Maskus (2001), and Markusen and Maskus (1999). ${ }^{2}$ All three use data on U.S. affiliate sales abroad (outbound affiliate sales) and sales of foreign affiliates in the U.S. (inbound affiliate sales) from 1986 through 1994 to investigate the various models of MNE activity. All three papers motivate reduced-form empirical specifications from simulated topologies of MNE activity over alternative variable and parameter spaces derived from the general equilibrium modeling of Markusen in previous theory work. The topologies are often nonlinear, leading

\footnotetext{
${ }^{2}$ S. Lael Brainard (1997) develops a horizontal MNE model where firms are located to foreign markets for "proximity advantages" and finds evidence consistent with the horizontal model using U.S. data. Karolina Ekholm (1995, 1997, 1998a,b) empirically examines implications of Markusen's knowledgecapital model, but does not try to connect it as directly to the theory as in the three papers we discuss in this section.
} 
to interaction and squared terms in the empirical specification. In particular, CMM pools observations of both inbound and outbound U.S. affiliate sales, tests it on a theory-motivated empirical specification of the knowledge-capital model and finds seemingly robust support for this MNE model. Markusen and Maskus (2001) extend CMM work by exploring additional empirical implications of the knowledgecapital model and estimating whether these exist in the same data set of inbound and outbound U.S. affiliate activity. While that paper still concludes that there is substantial evidence for the knowledgecapital model, they find a surprising result that skilled-labor abundance differences (parent minus host) are significantly negatively related to FDI activity in the outbound U.S. data. Furthermore, the coefficient on skill differences interacted with GDP differences is positive and significant. These results conflict with the predictions CMM provide for the knowledge-capital model.

Markusen and Maskus (2001) suggest that the difference with CMM could derive from two sources. First, the theory models a two-country world where total world endowments are fixed, whereas their dataset contains observations on country-pair observations with varying endowment totals. Since it is unclear what impact this might have on the model's predictions, the results for outbound affiliate activity in Markusen and Maskus (2001) may not contradict the knowledge-capital model. Second, they note that it may be problematic that the U.S. is one of the two countries in every country-pair observation in their sample. Since the U.S. is substantially larger than every other country, this restricts the observations to only a certain region of the parameter space, which could then skew the empirical results.

Finally, Markusen and Maskus (1999) use the same database of U.S. inbound and outbound affiliate activity as in CMM to examine an empirical specification that they present as nesting all three models of MNE activity: horizontal, vertical and knowledge-capital. Their empirical framework differs from that found in CMM. Whereas CMM specified skill differences as the difference between the skilled-labor abundance of the parent to the host country, Markusen and Maskus (1999) include additional interaction terms that indicate when this relative skill difference between the parent and host country is positive versus when it is negative; i.e., when the parent country is relatively skilled-labor abundant versus when the parent country is skilled-labor deficient. As we explain and demonstrate in this paper, 
this distinction between regions when the skill difference is negative versus when it is positive is critical. The empirical evidence in Markusen and Maskus (1999) strongly supports the horizontal model, and rejects the vertical and knowledge-capital models, which contrasts sharply with the conclusion of CMM.

Taken together, the recent evidence on MNE models presents a puzzle. Since all three papers use the same database on U.S. inbound and outbound MNE activity and are derived from the knowledgecapital model, why do they produce contradictory results regarding skill differences?

As the effect of differences between the parent and host country skill endowments is the major distinction between the predictions of the knowledge-capital and horizontal models, the resolution of the puzzle rests with this issue. The key is to realize that interpretation of the coefficients on such a difference variable depend critically on whether the sign of the difference term is negative or positive. When the skill difference term lies in the positive range, an increase in the variable corresponds to a to greater inequality in relative skill endowments. However, when the skill difference term is negative, parent and host country skill endowments converge as the difference term rises. As a result, it is incorrect to estimate a pooled coefficient on a difference term that takes both positive and negative values in the sample. As shown by Stephen E. Haynes and Joe A. Stone (1984), difference terms impose a subtractive linear constraint which can lead to a sign reversal in the pooled (or restricted) coefficient. Haynes and Stone show that this sign reversal indeed occurs in the estimation of a real interest rate differential model of the exchange rate by Jeffrey Frankel (1979), and we likewise show the same problem of sign reversal occurs in CMM.

For the bilateral U.S. affiliate data used by the papers discussed above, the skill difference term lies predominately in the positive region for U.S. outbound affiliate activity and predominately in the negative range for the inbound affiliate activity in the U.S. With both inbound and outbound affiliate sales pooled into one sample as in CMM, it is difficult to interpret the single coefficient on the skill difference term since it takes both positive and negative values. If the knowledge-capital model is correct and one separates out the skill difference terms into those observations where it is in the positive region 
(i.e., outbound U.S. affiliate activity) and the negative region (i.e., inbound activity), we would expect the same coefficient signs in both regions. In contrast, the horizontal model predicts opposing signs.

In fact, Markusen and Maskus (2001) obtain "correct" signs for the knowledge-capital model in the inbound sample, whereas the outbound sample has the reverse signs. Thus FDI activity decreases when absolute skill differences rise. Even more convincingly, Markusen and Maskus (1999) specifically take into account the expected sign reversal by interacting the skill difference with a dummy variable indicating whether the difference term is in the negative or positive region. They conclude that the since the signs in their empirical analysis are exactly the opposite of those predicted by the knowledge-capital model in CMM, the data supports the horizontal model. In their discussion of this discrepancy between the two papers, they do not attribute the resolution of the puzzle to the issue of whether the difference term is generally in the negative region or the positive region.

\section{Results}

To examine our proposed resolution, we obtained the data used in CMM from the authors. We were able to exactly replicate their results for all their reported specifications. Columns 1 and 3 of our Table 1 show coefficient estimates for the knowledge-capital model using OLS and Tobit specifications that correspond exactly to those CMM report in their Table 3.

We then modify their framework into what we term an absolute value model where we specify the skill difference and GDP difference terms as absolute values. Specification of the difference terms in absolute values implies that the new variable is always increasing in skill dissimilarity. This facilitates interpretation of coefficients and marginal effects of these regressors. Columns 2 and 4 of Table 1 report coefficient estimates for our absolute value version of the knowledge-capital model for the OLS and Tobit specifications, respectively. The results are striking. The coefficients on both the absolute skill difference term and its interaction with the absolute GDP difference are statistically significant at the $1 \%$ significance level and of opposite signs to those of CMM. The independent effect of skill differences now strongly suggests that real affiliate sales decrease as skill levels diverge - the opposite result from the 
sign predicted by CMM for the knowledge-capital model. Likewise, the interaction term of skill difference with GDP difference has the opposite sign and statistically significant at the $1 \%$ level when the difference terms are specified in absolute values. This too conflicts with the predicted sign of the knowledge-capital model. ${ }^{3}$ Finally, the $\mathrm{R}^{2}$ rises substantially in the OLS model when using the absolute value model (from 0.46 to 0.59 ) and the value of the log-likelihood increases for the Tobit specification (from -5755 to -5716). The original CMM article also presented a weighted least squares (WLS) specification, as well as host-country fixed effects versions of the OLS, WLS and Tobit specifications. We obtain identical changes in the signs of the skill-difference regressors when using the absolute value model that are statistically significant at the $1 \%$ level for all of these additional specifications (these results are available upon request). In summary, once these skill difference terms are appropriately specified, the data offer no support for the predictions of the knowledge-capital model with respect to skill differences between countries

The use of an absolute difference model, however, still involves a restriction that skill differences have symmetric effects on real affiliate sales. In other words, the relationship between absolute skill differences and real affiliate sales is identical for instances where the parent country is more skilled abundant compared to the host (skill difference term is positive in value), as well as where the host country is more skilled abundant compared to the parent (skill difference term is negative in value). In the U.S. data used by CMM, the former instance of positive skill differences is almost entirely observations of U.S. affiliate sales abroad (outbound affiliate sales), and the latter instance is almost entirely observations of foreign affiliate sales in the U.S. (inbound affiliate sales).

In Columns 1 and 2 of Table 2, we split the CMM sample into observations where the skill difference is always positive and where the skill difference term is always negative. If divergence in skill levels leads to a symmetric decline in real affiliate sales, then we should expect a negative coefficient on the skill difference term in the sample of positive skill differences and a positive coefficient for the

\footnotetext{
${ }^{3}$ The other RHS term in which skill difference enters in the CMM empirical framework is the interaction of the squared Skill Difference with Trade Cost Host. Since it is squared, no absolute value correction is needed for this term.
} 
sample of negative skill differences and they should be of comparable magnitude. The signs of coefficients in columns 1 and 2 of Table 2 confirm the sign expectation and again support the horizontal model predictions. The magnitudes, however, are not of equal size, with the coefficient on skill difference for the sample of negative skill differences almost three times as large. As we will discuss below, the marginal effects of skill differences on real affiliate sales (which also takes into account the interactions of skill difference with GDP difference and host-country trade costs) exhibit a similar change in magnitude.

For comparison, columns 3 and 4 of Table 2 provide estimates for separate samples of outbound and inbound affiliate activity. The coefficients on the skill difference terms likewise show opposite signs across the sample indicating that real affiliate sales and absolute skill differences are negatively related, in contrast with CMM's predictions for the knowledge-capital model. For the outbound-inbound split, the skill-difference coefficient is now larger for the outbound sample, not the inbound sample. This is seemingly inconsistent with the positive-negative sample split. However, in the marginal effects reported below, once one takes into account the interaction terms, the relative effects of skill difference on affiliate activity are qualitatively identical: an increase in skill difference leads to a decrease in affiliate activity that is approximately three times larger for the inbound (negative skill difference) sample as the outbound (positive skill difference) sample.

It is important to note that the opposite coefficients for the inbound and outbound sample correspond to the results found by Markusen and Maskus (2001). It is clear these opposing coefficient estimates for the two samples come from the fact that the skill difference is primarily negative in value in the inbound sample and positive in the outbound sample.

\section{A. Marginal Effects.}

Given the interaction terms involving the skill difference term in the CMM framework, the coefficient estimate on the skill difference term is not the marginal effect. For the OLS and WLS regressions, the marginal effect is 


\section{$\partial($ Real Affiliate Sales) $/ \partial($ Skill Difference $)=$ \\ B3 + B4 (GDP Difference) $+2 * B 7 *($ Trade Cost Host $) *($ Skill Difference $)$,}

where B3 is the estimated coefficient on the skill difference term, B4 is the estimated coefficient on the interaction between skill difference and GDP difference, and B7 is the estimated coefficient on the interaction between skill difference squared and host country-trade costs. ${ }^{4}$ In Table 3 we report marginal effects for a standard deviation change in skill differences for our absolute value models in Table 1 and our sample splits in Table 2. The marginal effects in every case correspond to the estimated coefficient on the skill difference term by itself. In other words, the interaction terms are not counteracting the estimated independent effect of skill differences, and our inferences that skill differences are inversely related to real sales activity are confirmed and statistically significant.

The marginal effects for the specifications that correctly model skill differences all suggest an inverse relationship between skill differences and real affiliate sales activity that is substantial in magnitude. For example, at the means of the data, a standard deviation increase in the absolute skill difference (a change in the share of a country's skilled worker share of approximately 10 percentage points) reduces real affiliate sales by $\$ 7.1$ billion in the OLS absolute value model, where the average real affiliate sales in the sample is $\$ 15.8$ billion. When the sample is split into inbound and outbound activity, the economic effect of skill differences on real affiliate sales is revealed to be much more pronounced for inbound activity, where an increase in skill dissimilarity (a negative change in the skill difference term for all observations that are negative) leads to a $\$ 8.0$ billion decrease in real affiliate sales. This effect is over three times larger than the $\$ 2.3$ billion decrease on the outbound side for a standard deviation increase in skill differences.

Marginal effects of skill difference on real affiliate sales are also calculated and discussed in result 4 of CMM. Rather than calculating a single marginal effect at the means of the data, they calculate marginal effects for every bilateral pairing in the sample for the year 1991 and then report separate marginal effects for inbound and outbound observations. The signs of their marginal effects for inbound 
and outbound observations agree with the results we report here (real affiliate sales negatively related to absolute skill differences), even though their coefficient estimates on the skill difference terms are completely the opposite of ours. The reason CMM obtain negative marginal effects in the outbound sample despite a positive coefficient on the skill difference term (B3) is the presence of the negative coefficient on the interaction between skill and GDP differences (B4). As the US has a much higher GDP than the countries it invests in, the outbound sample's marginal effects are dominated by the GDP difference interaction term. While their marginal effects correspond in sign to ours, their marginal effects are still based on coefficient estimates that incorrectly pooled inbound and outbound observations. ${ }^{5}$ As a result, we find that their marginal effects strongly understate the relationship between skill differences and affiliate activity for any comparable calculation. ${ }^{6}$

In the end, our estimates suggest a significant negative relationship between skill dissimilarity and real affiliate sales for both inbound and outbound MNE activity. A simple scatterplot of the data also provides persuasive visual evidence of this relationship. Figure 1 plots real affiliate sales (averaged from 1986 to 1994) activity versus the skill difference term. MNE affiliate sales are largest when skill differences are closest to zero and decline as skill differences increase in either direction. While not perfectly comparable, Figure 1 suggests a theoretical relationship that is much more in line with figures of horizontal MNE activity in Markusen and Maskus (1999). Those figures differ from Figure 2 of CMM which depicts affiliate sales for a parent country in an Edgeworth box where the skill difference term gets more positive as one moves northwest from the diagonal and more negative as one moves southeast off the diagonal. Interestingly, Figure 2 of CMM is consistent with an inverse relationship between skill

\footnotetext{
${ }^{4}$ Marginal effects of the Tobit specifications must also take into account the truncation of the sample, which was apparently not done in CMM - see Panel E of Table 2.

${ }^{5}$ In other words, marginal effects depend on 1) the coefficient estimates and 2) the value of the variables used for the interaction terms: skill difference, GDP difference, and host trade cost. By calculating marginal effects at values of the data that corresponded to various inbound and outbound observations, CMM got closer to properly adjusting for the problem with the skill and GDP difference terms, but their marginal effects still use pooled coefficient estimates that did not account for this problem.

${ }^{6}$ Table 3 obviously compares marginal effects calculated at the means of the data. Another comparison can be made by calculating the marginal effects for every observation in the sample for both studies and then comparing the value of the median marginal effect from each sample. Their median marginal effect suggests that a standard deviation increase in skill differences leads to a $\$ 1.04$ billion fall in real affiliate sales, whereas ours suggests a $\$ 19.85$ billion fall.
} 
differences and affiliate sales for negative skill differences between the parent and host, but the same figure also shows little to no MNE activity unless the parent is not too skill-deficient from the host country. Predictions of little MNE activity for a skill-deficient parent are also displayed for the horizontal model in Markusen and Maskus (1999). This contrasts with the U.S. data that shows surprising inbound MNE activity from parent countries that are substantially skill-deficient to the U.S. Of course, the figures of affiliate activity created in CMM and Markusen and Maskus (1999) are for certain fixed parameter values, so it is not clear whether reasonable parameter values would yield figures that correspond more closely with the data.

\section{B. Exploring Alternative Samples.}

The CMM data cover a relatively small group of countries and years. Additionally, every observation of a bilateral country pair includes the United States, causing concern that the variation in the data is confined to only particular parameter spaces. For example, there are very few examples in the data of parent countries that are smaller than the host country, but which have a positive skill difference. ${ }^{7}$ The main reasons why the CMM data are limited in country and year coverage are data availability for their trade and investment cost variables and, to some extent, their proxy for skilled labor.

As a robustness check we constructed two alternative samples to estimate the knowledge-capital model. The first is what we call the modified U.S. sample. We make a number of changes to the variables used as proxies and expand the U.S. sample in the process. In particular, we use data on average educational attainment by country and year as a proxy for skilled-labor abundance, rather than the share of labor listed in skilled occupations that was used by CMM. Second, we turn to alternative trade and investment cost data that allowed greater coverage. Third, we used Penn World Table data for real GDP. ${ }^{8}$ Finally we use affiliate sales in all industries whereas CMM use sales in the manufacturing sector only (this feature of their data, not noted in the paper, results in a reduction in the sample of available

\footnotetext{
${ }^{7}$ A couple exceptions are some of the European countries which are indicated as relatively skilled-labor abundant to the U.S. in the data. But even in these cases the skill differences are very small.

${ }^{8}$ This step actually limits the sample to years through 1992, rather than 1994, as in CMM.
} 
countries because of disclosure issues.) The combined effect of these changes is a sample comprising over 50 percent more observations covering a slightly different set of countries, over somewhat different years, with quite different proxies for our variables. The appendix has details on data sources, variable construction and descriptive statistics.

Columns 1 and 2 of Table 4 show that despite the many changes in the sample and variable construction, we obtain the same OLS results using this modified U.S. sample as we did in Table 1 using the CMM data sample. Estimation of the CMM framework with simple skill and GDP difference terms yields a relatively small positive coefficient on the skill difference term, while the absolute value model yields a much larger negative coefficient, which contradicts the predicted signs of the knowledge-capital model. As reported in Table 3, the marginal effect for the absolute value model is also statistically significant and suggests a strong inverse relationship between skill differences and real affiliate sales. Running separate samples of inbound and outbound observations (or positive and negative skilldifference observations) for this modified U.S. sample again suggests, as with the CMM sample, that the inverse relationship between absolute skill differences and real affiliate sales is much more substantial for inbound affiliate activity (or where parent-host skill differences are negative). These results are available on request.

The second alternative we consider is a sample of FDI activity involving OECD countries, which helps to alleviate the problems caused by using a sample where one of the countries in every bilateral-pair observation is the U.S. We collected OECD data on FDI stock, since data on affiliate sales for countries other than the U.S. are generally not collected, and matched these data with the proxy variables for GDP, skill, and trade/investment costs used in our modified U.S. sample. This created a sample of 2460 covering 15 OECD parent countries and 38 host countries (some OECD and some non-OECD) over the years 1982 through 1992. Again, this is an important sample to consider because it considers a much broader range of possible bilateral pairings than when one is confined to data where the U.S. is necessarily one of the countries in the bilateral pair. In addition, the constructed dataset includes almost 2500 observations - a much larger sample than either of the two U.S. samples we use. The tradeoff is 
that the data are likely not as accurate, with greater measurement error with the FDI stock data proxying for affiliate activity and measurement consistency problems across countries. In the appendix, we discuss these issues further, as well as details on data sources, variable construction and descriptive statistics.

Columns 3 and 4 of Table 4 report OLS results for the CMM difference model and our absolute difference model for this OECD sample. The results are consistent with our findings using U.S. data. The CMM difference model gives a pooled coefficient that is positive on the skill difference term, while the absolute value model estimates an inverse relationship between skill differences and our dependent variable, real FDI stock. While the coefficient on the absolute skill difference term is not statistically significant at standard confidence levels, the marginal effect of absolute skill differences (as reported in Table 3) is substantial and statistically significant. At the means of the data, a standard deviation increase in the skill difference term (about 2.5 years difference in average educational attainment) means a $\$ 3.3$ billion decrease in FDI stock by the parent country in the host country. This is a substantial amount, given a sample average of $\$ 4.3$ billion FDI stock. These results provide some evidence that the negative relationship between absolute skill differences and FDI activity is a worldwide phenomenon, not confined to the U.S.

\section{Conclusions}

This paper identifies and corrects an econometric specification problem that led to incorrect inferences in CMM about the efficacy of the knowledge-capital model. The empirical framework of CMM estimates coefficients on difference terms that must be interpreted in an opposite manner depending on whether such difference terms are negative or positive in value. CMM incorrectly estimate pooled coefficients over a sample of negative- and positive-valued difference terms. Their estimates coincidently affirm the predictions of the knowledge-capital model. However, when a correct specification of the difference terms is employed, either by taking absolute values or running separate samples for positive and negative-valued observations, we obtain coefficient signs that do not support the knowledge-capital model. These results arise not only for the sample of U.S. bilateral 
observations on MNE affiliate sales employed by CMM, but also for U.S. samples with alternative proxies for key variables, as well as a sample of FDI activity across OECD countries.

Beyond pointing out the econometric misspecification in CMM, this comment also shows that a variety of databases on MNE activity show a strong negative relationship between skill dissimilarity and affiliate sales. This evidence suggests that Markusen and Venables' (2000) horizontal model of FDI cannot be rejected in favor of the knowledge-capital model of Markusen et al (1996). We acknowledge that it is possible for skill dissimilarity to be inversely related to affiliate sales in the knowledge-capital model, but this is true only for certain parameter spaces of the knowledge-capital model. In general, the vertical MNE features of the knowledge-capital model, which would suggest greater MNE activity for greater skill differences, are at odds with the broad trends in the data. We caution that this does not necessarily imply that vertical MNE activity does not exist in the real world, but simply reflects that the preponderance of activity is horizontal in nature or, at least, between the rich countries of the world, where skill differences are relatively small. ${ }^{9}$

On a final note, we have used the CMM empirical specification to test the predictions of the knowledge-capital model. As CMM note, the underlying theoretical MNE model is quite complex, requiring numerical methods to solve a system of over 40 equations. As a matter of necessity, one must therefore work empirically with approximations of the model. The problem of identifying the most appropriate empirical specification within which to test MNE model implications merits further research.

\footnotetext{
${ }^{9}$ For example, see Hanson and Feenstra (1999), Slaughter (2000), and Hanson et al. (2001), for evidence of U.S. vertical MNE activity.
} 
Table 1: OLS Results using CMM Results Versus Results from Absolute Difference Version of Knowledge-capital model.

\begin{tabular}{|c|c|c|c|c|}
\hline \multirow[b]{2}{*}{ Regressors } & \multicolumn{2}{|c|}{ OLS } & \multicolumn{2}{|c|}{ Tobit } \\
\hline & $\begin{array}{c}\text { Table } 3 \\
\text { Results from } \\
\text { CMM } \\
\end{array}$ & $\begin{array}{c}\text { Absolute } \\
\text { Difference } \\
\text { Model }\end{array}$ & $\begin{array}{c}\text { Table } 3 \\
\text { Results from } \\
\text { CMM } \\
\end{array}$ & $\begin{array}{c}\text { Absolute } \\
\text { Difference } \\
\text { Model } \\
\end{array}$ \\
\hline GDP Sum & $\begin{array}{l}10.80^{* *} \\
(7.01)\end{array}$ & $\begin{array}{l}17.57 * * \\
(12.13)\end{array}$ & $\begin{array}{l}15.04 * * \\
(10.27)\end{array}$ & $\begin{array}{l}21.24^{* *} \\
(15.02)\end{array}$ \\
\hline GDP Difference Squared & $\begin{array}{c}-0.0012 * * \\
(-6.89) \\
\end{array}$ & $\begin{array}{c}-0.0040 * * \\
(-14.77) \\
\end{array}$ & $\begin{array}{c}-0.0010 * * \\
(-5.89) \\
\end{array}$ & $\begin{array}{c}-0.0037 * * \\
(-13.19) \\
\end{array}$ \\
\hline $\begin{array}{l}\text { Skill Difference } \\
\left(=\text { Skill }_{\mathrm{p}}-\text { Skill }_{\mathrm{h}}\right)\end{array}$ & $\begin{array}{l}33743 * * \\
(3.77)\end{array}$ & & $\begin{array}{l}61700^{* *} \\
(7.28)\end{array}$ & \\
\hline $\begin{array}{l}\text { Skill Difference * GDP } \\
\text { Difference }\left(=\left(\text { Skill }_{\mathrm{p}}-\mathrm{Skill}_{\mathrm{h}}\right)^{*}\right. \\
\left.\left(\mathrm{GDP}_{\mathrm{p}}-\mathrm{GDP}_{\mathrm{h}}\right)\right)\end{array}$ & $\begin{array}{l}-6.34 * * \\
(-2.62)\end{array}$ & & $\begin{array}{l}-10.20 * * \\
(-4.34)\end{array}$ & \\
\hline $\begin{array}{l}\text { Absolute Skill Difference } \\
\left(=\mid \text { Skill }_{\mathrm{p}}-\text { Skill }_{\mathrm{h}} \mid\right)\end{array}$ & & $\begin{array}{c}-1485525^{* *} \\
(-12.85)\end{array}$ & & $\begin{array}{c}-1428759 * * \\
(-12.07)\end{array}$ \\
\hline $\begin{array}{l}\text { Absolute Skill Difference * } \\
\text { Absolute GDP Difference } \\
\left(=\mid \text { Skill }_{\mathrm{p}}-\text { Skill }_{\mathrm{h}}|*| \mathrm{GDP}_{\mathrm{p}}-\right. \\
\left.\mathrm{GDP}_{\mathrm{h}} \mid\right)\end{array}$ & & $\begin{array}{l}253.39 * * \\
(12.08)\end{array}$ & & $\begin{array}{l}234.21 * * \\
(10.87)\end{array}$ \\
\hline Investment Cost Host & $\begin{array}{l}-516.6^{* *} \\
(-3.79)\end{array}$ & $\begin{array}{l}-173.1 \\
(-1.75)\end{array}$ & $\begin{array}{l}-387.6^{* *} \\
(-2.82)\end{array}$ & $\begin{aligned} 229.8 \\
(2.39)\end{aligned}$ \\
\hline Trade Cost Host & $\begin{array}{l}119.2 \\
(1.16) \\
\end{array}$ & $\begin{array}{l}-109.2 \\
(-1.08) \\
\end{array}$ & $\begin{array}{l}156.2 \\
(1.51) \\
\end{array}$ & $\begin{array}{l}-227.3^{*} \\
(-2.22) \\
\end{array}$ \\
\hline $\begin{array}{l}\text { Trade Cost Host * Squared } \\
\text { Skill Difference }\end{array}$ & $\begin{array}{l}605.2 \\
(0.36)\end{array}$ & $\begin{array}{l}5997 * * \\
(2.84)\end{array}$ & $\begin{array}{l}-1264 \\
(-0.75)\end{array}$ & $\begin{array}{l}6896^{* *} \\
(3.15)\end{array}$ \\
\hline Trade Cost Parent & $\begin{array}{l}-93.7 \\
(-0.99) \\
\end{array}$ & $\begin{array}{l}-108.6 \\
(-1.32) \\
\end{array}$ & $\begin{array}{r}-122.0 \\
(-1.46) \\
\end{array}$ & $\begin{array}{c}-201.2 * * \\
(-2.75) \\
\end{array}$ \\
\hline Distance & $\begin{array}{l}-1.82 * * \\
(-7.75) \\
\end{array}$ & $\begin{array}{l}-1.31 * * \\
(-6.34) \\
\end{array}$ & $\begin{array}{l}-1.48 * * \\
(-6.47) \\
\end{array}$ & $\begin{array}{l}-1.00 * * \\
(-4.86) \\
\end{array}$ \\
\hline Intercept & $\begin{array}{l}16630 \\
(1.08) \\
\end{array}$ & $\begin{array}{l}57437 * * \\
(4.18) \\
\end{array}$ & $\begin{array}{r}-23283 \\
(-1.61) \\
\end{array}$ & $\begin{array}{l}17300 \\
(1.29) \\
\end{array}$ \\
\hline Observations & 509 & 509 & 628 & 628 \\
\hline Adjusted $\mathrm{R}^{2}$ & 0.46 & 0.59 & & \\
\hline Log-likelihood & & & -5755 & -5716 \\
\hline
\end{tabular}

NOTES: $\mathrm{p}=$ parent, $\mathrm{h}=$ host. $\mathrm{t}$-statistics are in parentheses with ${ }^{* *}$ and ${ }^{*}$ denoting statistical significance (two-tailed test) at the 1 and 5 percent levels, respectively. 
Table 2: OLS Results Using CMM Framework to Compare Estimates from Sample with Positive Skill Differences Versus Sample with Negative Skill Differences and Sample of Outbound U.S. Affiliate Sales Versus Sample of Inbound U.S. Affiliate Sales

\begin{tabular}{|c|c|c|c|c|}
\hline Regressors & $\begin{array}{c}\text { Sample with } \\
\text { positive skill } \\
\text { differences } \\
\end{array}$ & $\begin{array}{c}\text { Sample with } \\
\text { negative skill } \\
\text { differences } \\
\end{array}$ & $\begin{array}{l}\text { Outbound } \\
\text { Sample }\end{array}$ & $\begin{array}{l}\text { Inbound } \\
\text { Sample }\end{array}$ \\
\hline GDP Sum & $\begin{array}{l}9.21^{* *} \\
(5.86)\end{array}$ & $\begin{array}{l}13.14 * * \\
(4.04)\end{array}$ & $\begin{array}{l}15.50 * * \\
(9.16)\end{array}$ & $\begin{array}{l}22.37 * * \\
(8.18)\end{array}$ \\
\hline GDP Difference Squared & $\begin{array}{c}-0.0014 * * \\
(-7.5)\end{array}$ & $\begin{array}{c}-0.0012 * * \\
(-3.56)\end{array}$ & $\begin{array}{l}-0.0045^{* *} \\
(-15.08)\end{array}$ & $\begin{array}{c}-0.0024 * * \\
(-7.10)\end{array}$ \\
\hline $\begin{array}{l}\text { Skill Difference } \\
\left(=\text { Skill }_{\mathrm{p}}-\text { Skill }_{\mathrm{h}}\right)\end{array}$ & $\begin{array}{c}-81147 * * \\
(-2.83)\end{array}$ & $\begin{array}{l}220693 * * \\
(2.66)\end{array}$ & $\begin{array}{c}-1575770 * * \\
(-13.02)\end{array}$ & $\begin{array}{l}989126^{* *} \\
(7.78)\end{array}$ \\
\hline $\begin{array}{l}\text { Skill Difference } * \text { GDP } \\
\text { Difference }\left(=\left(\text { Skill }_{\mathrm{p}}-\mathrm{Skill}_{\mathrm{h}}\right)^{*}\right. \\
\left.\left(\mathrm{GDP}_{\mathrm{p}}-\mathrm{GDP}_{\mathrm{h}}\right)\right)\end{array}$ & $\begin{array}{c}5.33 \\
(1.50)\end{array}$ & $\begin{array}{l}-10.82 \\
(-1.49)\end{array}$ & $\begin{array}{l}289.95 * * \\
(12.87)\end{array}$ & $\begin{array}{l}172.4^{* *} \\
(7.34)\end{array}$ \\
\hline Investment Cost Host & $\begin{array}{c}-522.3^{* *} \\
(-3.96) \\
\end{array}$ & $\begin{array}{l}-1097 \\
(-1.37)\end{array}$ & $\begin{array}{l}-1031 * * \\
(-7.88)\end{array}$ & $\begin{array}{l}389.2 \\
(0.36)\end{array}$ \\
\hline Trade Cost Host & $\begin{array}{c}52.3 \\
(0.47) \\
\end{array}$ & $\begin{array}{l}-46.3 \\
(-0.12)\end{array}$ & $\begin{array}{l}417.8^{* *} \\
(4.37)\end{array}$ & $\begin{array}{l}-39.7 \\
(-0.12)\end{array}$ \\
\hline $\begin{array}{l}\text { Trade Cost Host * Squared } \\
\text { Skill Difference }\end{array}$ & $\begin{array}{c}3863 \\
(1.82) \\
\end{array}$ & $\begin{array}{c}27825^{*} \\
(2.50)\end{array}$ & $\begin{array}{l}540.6 \\
(0.33)\end{array}$ & $\begin{array}{l}-3047 \\
(-1.11)\end{array}$ \\
\hline Trade Cost Parent & $\begin{array}{r}-420.5^{*} \\
(-2.46) \\
\end{array}$ & $\begin{array}{l}-73.0 \\
(-0.52)\end{array}$ & $\begin{array}{l}123.4 \\
(0.52)\end{array}$ & $\begin{array}{r}-2.80 \\
(-0.03) \\
\end{array}$ \\
\hline Distance & $\begin{array}{l}-1.59 * * \\
(-6.25)\end{array}$ & $\begin{array}{l}-2.21 * * \\
(-5.14)\end{array}$ & $\begin{array}{l}-2.17^{* *} \\
(-8.16)\end{array}$ & $\begin{array}{l}-0.73^{* *} \\
(-2.67)\end{array}$ \\
\hline Intercept & $\begin{array}{l}46694^{* *} \\
(2.86) \\
\end{array}$ & $\begin{array}{r}34589 \\
(0.88) \\
\end{array}$ & $\begin{array}{c}92987 * * \\
(5.56) \\
\end{array}$ & $\begin{array}{l}-52763 \\
(-1.23) \\
\end{array}$ \\
\hline Observations & 306 & 203 & 310 & 199 \\
\hline Adjusted $\mathrm{R}^{2}$ & 0.54 & 0.45 & 0.67 & 0.64 \\
\hline
\end{tabular}

NOTES: $\mathrm{p}=$ parent, $\mathrm{h}=$ host. $\mathrm{t}$-statistics are in parentheses with ${ }^{* *}$ and $*$ denoting statistical significance (two-tailed test) at the 1 and 5 percent levels, respectively. 
Table 3: Marginal Effects of Skill Differences on Real Affiliate Sales/Stock Evaluated at the Means of the Data.

\begin{tabular}{|c|c|c|c|}
\hline Model & $\begin{array}{c}\text { Change in real } \\
\text { affiliate sales/stock for } \\
\text { a standard deviation } \\
\text { change in skill } \\
\text { differences } \\
\end{array}$ & $\begin{array}{l}\text { F-Statistic } \\
\text { (P-value) }\end{array}$ & $\begin{array}{c}\text { Sample average real } \\
\text { affiliate sales/stock }\end{array}$ \\
\hline $\begin{array}{l}\text { CMM Sample } \\
\text { CMM OLS Difference Model } \\
\text { (Column } 1 \text { of table } 2)\end{array}$ & 3308 & $\begin{array}{c}10.66 \\
(0.000)\end{array}$ & 15767 \\
\hline $\begin{array}{l}\text { OLS Absolute Difference Model } \\
\text { (Column } 2 \text { of table } 2)\end{array}$ & -7137 & $\begin{array}{c}65.02 \\
(0.000) \\
\end{array}$ & 15767 \\
\hline $\begin{array}{l}\text { CMM Tobit Difference Model } \\
\text { (Column } 3 \text { of table } 2 \text { ) }\end{array}$ & 2981 & $\begin{array}{c}53.88 \\
(0.000)\end{array}$ & 12779 \\
\hline $\begin{array}{l}\text { Tobit Absolute Difference Model } \\
\text { (Column } 4 \text { of table } 2 \text { ) }\end{array}$ & -6531 & $\begin{array}{r}127.25 \\
(0.000) \\
\end{array}$ & 12779 \\
\hline $\begin{array}{l}\text { OLS Difference Model, Positive } \\
\text { Sample (Column } 1 \text { of Table 3) }\end{array}$ & -2119 & $\begin{array}{c}3.68 \\
(0.056) \\
\end{array}$ & 14589 \\
\hline $\begin{array}{l}\text { OLS Difference Model, Negative } \\
\text { Sample (Column } 2 \text { of Table } 3 \text { ) }\end{array}$ & 6576 & $\begin{array}{c}10.77 \\
(0.001) \\
\end{array}$ & 17542 \\
\hline $\begin{array}{l}\text { OLS Difference Model, Outbound } \\
\text { Sample (Column } 3 \text { of Table 3) }\end{array}$ & -2329 & $\begin{array}{c}3.96 \\
(0.048) \\
\end{array}$ & 15942 \\
\hline $\begin{array}{l}\text { OLS Difference Model, Inbound } \\
\text { Sample (Column } 4 \text { of Table 3) }\end{array}$ & 7975 & $\begin{array}{c}50.03 \\
(0.000)\end{array}$ & 15494 \\
\hline $\begin{array}{l}\text { Modified U.S. Sample } \\
\text { OLS Absolute Difference Model } \\
\text { (Column } 2 \text { of table 5) }\end{array}$ & -15966 & $\begin{array}{l}216.6 \\
(0.000)\end{array}$ & 20821 \\
\hline $\begin{array}{l}\text { OECD Sample } \\
\text { OLS Absolute Difference Model } \\
\text { (Column } 4 \text { of table } 5)\end{array}$ & -3361 & $\begin{array}{c}90.92 \\
(0.000)\end{array}$ & 4322 \\
\hline
\end{tabular}

Notes: All marginal effects are calculated at the means of the data. Real affiliate sales (real stock for OECD) are in millions of real U.S. dollars. Wald statistic, not F-statistic, was calculated for Tobit marginal effects. 
Table 4: OLS Results for Modified U.S. Sample and OECD Sample.

\begin{tabular}{|c|c|c|c|c|}
\hline \multirow[b]{2}{*}{ Regressors } & \multicolumn{2}{|c|}{ Modified U.S. Sample } & \multicolumn{2}{|c|}{ OECD Sample } \\
\hline & $\begin{array}{c}\text { Difference } \\
\text { Model }\end{array}$ & $\begin{array}{c}\text { Absolute } \\
\text { Difference } \\
\text { Model } \\
\end{array}$ & $\begin{array}{c}\text { Difference } \\
\text { Model }\end{array}$ & $\begin{array}{r}\text { Absolute } \\
\text { Difference } \\
\text { Model } \\
\end{array}$ \\
\hline GDP Sum & $\begin{array}{l}34.38^{* *} \\
(15.58)\end{array}$ & $\begin{array}{l}30.81^{* *} \\
(16.58)\end{array}$ & $\begin{array}{l}9.28 * * \\
(25.88) \\
\end{array}$ & $\begin{array}{l}9.26^{* *} \\
(26.25) \\
\end{array}$ \\
\hline GDP Difference Squared & $\begin{array}{c}-0.0035^{* *} \\
(-9.06)\end{array}$ & $\begin{array}{l}-0.0107 * * \\
(-21.36)\end{array}$ & $\begin{array}{c}-0.0007 * * \\
(-7.22)\end{array}$ & $\begin{array}{c}-0.0004 * * \\
(-4.51)\end{array}$ \\
\hline $\begin{array}{l}\text { Skill Difference } \\
\left(=\text { Skill }_{\mathrm{p}}-\text { Skill }_{\mathrm{h}}\right)\end{array}$ & $\begin{array}{l}1859^{* *} \\
(4.46) \\
\end{array}$ & & $\begin{array}{l}272.5^{* *} \\
(2.56)\end{array}$ & \\
\hline $\begin{array}{l}\text { Skill Difference * GDP } \\
\text { Difference }\left(=\left(\text { Skill }_{p}-\text { Skill }_{h}\right) *\right. \\
\left.\left(G^{*} P_{p}-G D P_{h}\right)\right)\end{array}$ & $\begin{array}{l}-0.24 \\
(-0.97)\end{array}$ & & $\begin{array}{l}-0.69 * * \\
(-10.76)\end{array}$ & \\
\hline $\begin{array}{l}\text { Absolute Skill Difference } \\
\left(=\mid \text { Skill }_{\mathrm{p}}-\text { Skill }_{\mathrm{h}} \mid\right)\end{array}$ & & $\begin{array}{l}-58510^{* *} \\
(-18.82)\end{array}$ & & $\begin{array}{l}-141.5 \\
(-0.78)\end{array}$ \\
\hline $\begin{array}{l}\text { Absolute Skill Difference * } \\
\text { Absolute GDP Difference } \\
\left(=\mid \text { Skill }_{\mathrm{p}}-\text { Skill }_{\mathrm{h}}|*| \mathrm{GDP}_{\mathrm{p}}-\right. \\
\left.\mathrm{GDP}_{\mathrm{h}} \mid\right)\end{array}$ & & $\begin{array}{l}12.34 * * \\
(16.77)\end{array}$ & & $\begin{array}{l}-0.97 * * \\
(-12.27)\end{array}$ \\
\hline Investment Cost Host & $\begin{array}{l}-763.7 * * \\
(-4.87) \\
\end{array}$ & $\begin{array}{l}143.3 \\
(1.93) \\
\end{array}$ & $\begin{array}{l}-46.2 * \\
(-2.27) \\
\end{array}$ & $\begin{array}{l}-5.58 \\
(-0.29) \\
\end{array}$ \\
\hline Trade Cost Host & $\begin{array}{c}68.9 \\
(1.80) \\
\end{array}$ & $\begin{array}{c}-172.4^{* *} \\
(-4.84) \\
\end{array}$ & $\begin{array}{l}-4.14 \\
(-0.92)\end{array}$ & $\begin{array}{c}-15.93^{* *} \\
(-3.56) \\
\end{array}$ \\
\hline $\begin{array}{l}\text { Trade Cost Host * Squared } \\
\text { Skill Difference }\end{array}$ & $\begin{array}{l}-5.18^{* *} \\
(-3.61) \\
\end{array}$ & $\begin{array}{l}4.66^{* *} \\
(3.18) \\
\end{array}$ & $\begin{array}{l}-1.38^{* *} \\
(-4.78) \\
\end{array}$ & $\begin{array}{l}-0.30 \\
(-0.96)\end{array}$ \\
\hline Trade Cost Parent & $\begin{array}{c}18.31 \\
(27.09) \\
\end{array}$ & $\begin{array}{l}-16.5 \\
(-0.73) \\
\end{array}$ & $\begin{array}{l}-69.9^{* *} \\
(-1.46) \\
\end{array}$ & $\begin{array}{l}-55.1^{* *} \\
(-4.88) \\
\end{array}$ \\
\hline Distance & $\begin{array}{l}-3.09^{* *} \\
(-6.61) \\
\end{array}$ & $\begin{array}{l}-2.13^{* *} \\
(-5.42) \\
\end{array}$ & $\begin{array}{l}-0.25 * * \\
(-5.74) \\
\end{array}$ & $\begin{array}{l}-0.24 * * \\
(-5.49) \\
\end{array}$ \\
\hline Intercept & $\begin{array}{r}-26122^{*} \\
(-2.01) \\
\end{array}$ & $\begin{array}{c}104349^{* *} \\
(8.00)\end{array}$ & $\begin{array}{l}726.5 \\
(0.77) \\
\end{array}$ & $\begin{array}{l}-443.6 \\
(-0.50) \\
\end{array}$ \\
\hline Observations & 778 & 778 & 2460 & 2460 \\
\hline Adjusted $\mathrm{R}^{2}$ & 0.52 & 0.67 & 0.37 & 0.39 \\
\hline
\end{tabular}

NOTES: $\mathrm{p}=$ parent, $\mathrm{h}=$ host. $\mathrm{t}$-statistics are in parentheses with ${ }^{* *}$ and ${ }^{*}$ denoting statistical significance (two-tailed test) at the 1 and 5 percent levels, respectively. 
Figure 1: Affiliate Sales (1986-1994 avgs)

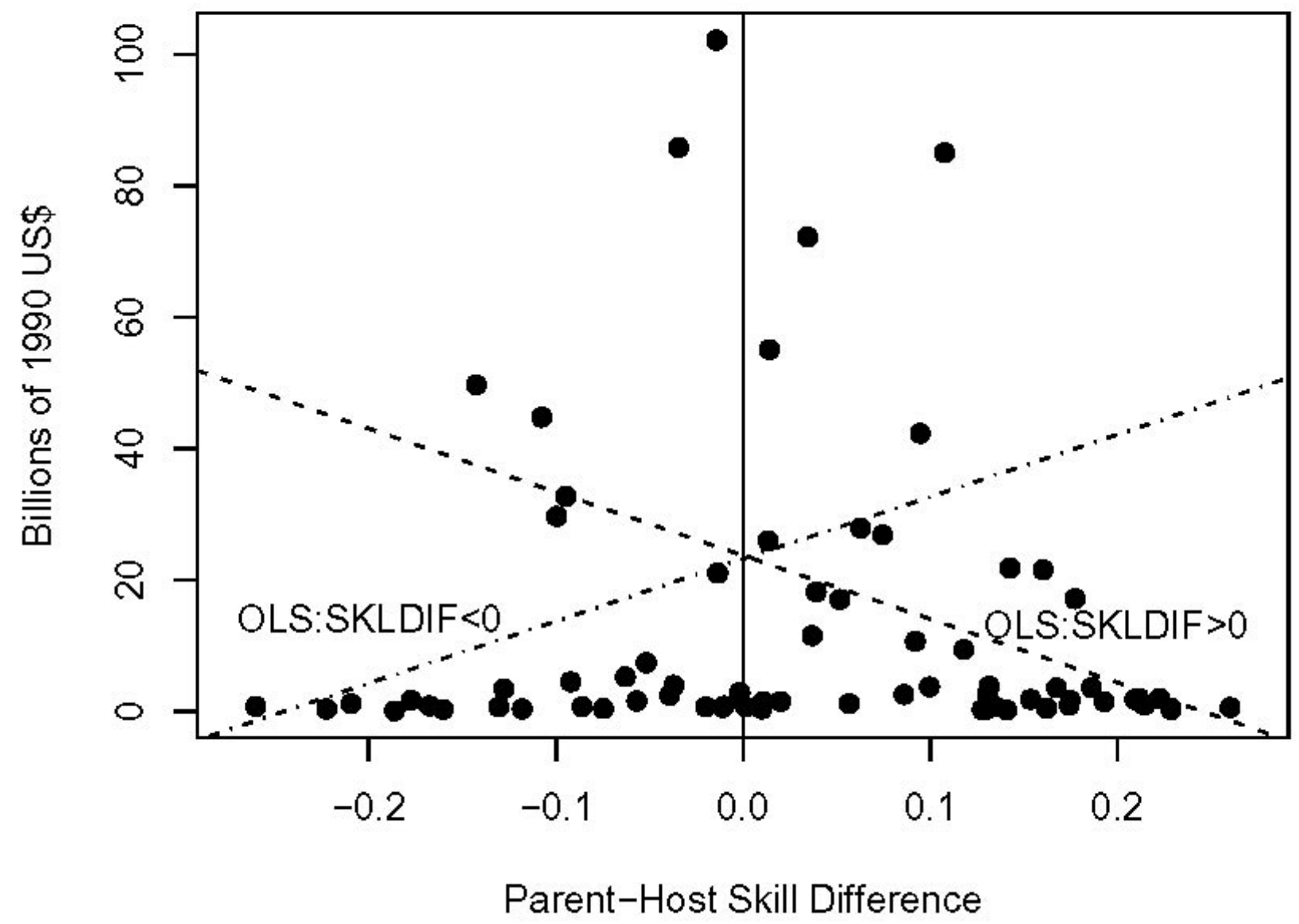




\section{References}

Brainard, S. Lael. "An Empirical Assessment of the Proximity-Concentration Trade-off Between Multinational Sales and Trade.” American Economic Review, September 1997, 87(4), pp. 520-44.

Carr, David L.; Markusen, James R. and Maskus, Keith E. "Estimating the Knowledge-Capital Model of the Multinational Enterprise." American Economic Review, June 2001, 91(3), pp. 693-708.

Ekholm, Karolina. Multinational Production and Trade in Technological Knowledge. Lund Economics Studies (Lund, Sweden), No. 58, Lund: University of Lund, March 1995.

. "Factor Endowments and the Pattern of Affiliate Production by Multinational Enterprises.” CREDIT (University of Nottingham) Working Paper, No. 97/19, 1997.

. (1998a), "Headquarter Services and Revealed Factor Abundance." Review of International Economics, November 1998a, 6(4), pp. 545-53.

. (1998b), "Proximity Advantages, Scale Economies, and the Location of Production," in Pontus Braunerhjelm and Karolina Ekholm, eds., The geography of multinational firms. Boston: Kluwer Academic Publishers, pp. 59-76.

Feenstra, Robert C. and Hanson, Gordon H. "The Impact of Outsourcing and High-Technology Capital on Wages: Estimates for the United States, 1979-1990." Quarterly Journal of Economics, August 1999, 114(3), pp. 907-40.

Frankel, Jeffrey. "On the Mark: A Theory of Floating Exchange Rates Based on Real Interest Differential." American Economic Review, September 1979, 69(4), pp. 610-22.

Graham, Edward M. and Krugman, Paul R. Foreign Direct Investment in the United States, Third Edition. Washington, DC: Institute for International Economics, 1995.

Hanson, Gordon H.; Mataloni Jr., Raymond J. and Slaughter, Matthew J. "Expansion Strategies of U.S. Multinational Firms." National Bureau of Economic Research (Cambridge, MA) Working Paper No. 8433, August 2001.

Haynes, Stephen E. and Stone, Joe A. (1981), "On the Mark: Comment." American Economic Review, December 1981, 71(5), pp. 1060-67.

Helpman, Elhanan. "A Simple Theory of International Trade with Multinational Corporations." Journal of Political Economy, June 1984, 94(3), pp. 451-71.

Helpman, Elhanan and Krugman, Paul R. Trade and market structure. Cambridge, MA: MIT Press, 1985.

Horstmann, Ignatius J. and Markusen, James R. "Strategic Investments and the Development of Multinationals." International Economic Review, February 1987, 28(1), pp. 109-21.

Horstmann, Ignatius J. and Markusen, James R. "Endogenous Market Structures in International Trade." Journal of International Economics, February 1992, 32(1/2), pp. 109-29.

Markusen, James R. "Multinationals, Multi-plant Economies, and the Gains from Trade." Journal of International Economics, May 1984, 16(3/4), pp. 205-26. 
Markusen, James R. "Trade versus Investment Liberalization," National Bureau of Economic Research (Cambridge, MA) Working Paper No. 6231, October 1997.

Markusen, James R. and Maskus, Keith E. "Discriminating Among Alternative Theories of the Multinational Enterprise," National Bureau of Economic Research (Cambridge, MA) Working Paper No. 7164, June 1999.

Markusen, James R. and Maskus, Keith E. "Multinational Firms: Reconciling Theory and Evidence," in Magnus Blomstrom and Linda S. Goldberg, eds., Topics in Empirical International Economics: A Festschrift in Honor of Robert E. Lipsey. Chicago, IL: University of Chicago Press for National Bureau of Economic Research, 2001.

Markusen, James R. and Venables, Anthony J. "The Role of Multinational Firms in the Wage-gap Debate." Review of International Economics, November 1997, 5(4), pp. 435-51.

Markusen, James R. and Venables, Anthony J. "Multinational Firms and the New Trade Theory." Journal of International Economics, December 1998, 46(2), pp. 183-203.

Markusen, James R. and Venables, Anthony J. "The Theory of Endowment, Intra-Industry and Multinational Trade.” Journal of International Economics, December 2000, 52(2), pp. 209-34.

Markusen, James R.; Venables, Anthony J., Eby-Konan, Denise and Zhang, Kevin Honglin. “A Unified Treatment of Horizontal Direct Investment, Vertical Direct Investment, and the Pattern of Trade in Goods and Services," National Bureau of Economic Research (Cambridge, MA) Working Paper No. 5696, August 1996.

Slaughter, Matthew J. "Production Transfer within Multinational Enterprises and American Wages." Journal of International Economics, April 2000, 50(2), pp. 449-72. 


\section{Appendix}

This appendix provides details on data sources and variable construction for the modified U.S. and OECD data samples used in the econometric analysis reported in Table 5.

\section{U.S. Modified Sample}

As in CMM, we rely on U.S. Bureau of Economic Analysis (BEA) data on affiliate sales for our dependent variable. We converted our affiliate sales into millions of real U.S. dollars using the U.S. GDP deflator as reported in the Economic Report of the President and the yearly average exchange rate as reported by the International Monetary Funds International Financial Statistics. Affiliate sales are perhaps the most reliable measure of FDI activity (as opposed to FDI flows or stocks) since they can be compared across time and industries with less concern over divergent accounting methodologies. These data are available at the BEA's Internet site and go back to 1983 for U.S. outbound sales and 1984 for U.S. inbound sales, though data availability concerns with respect to other sample variables limited CMM to using only data after 1986 . Our alternative proxies discussed next allow our sample to extend back to 1983 and 1984 for U.S. outbound and inbound affiliate sales, respectively.

For variables using real GDP in both the modified U.S. and OECD samples, we use the Penn World Tables real GDP measures available at http://datacentre.chass.utoronto.ca:5680/pwt/ and described by Summers and Heston (1991). In contrast, the CMM database constructs real GDP data from the International Financial Statistics (IFS) published by the International Monetary Fund. The Penn World Tables data only extend until 1992, while the IFS data allowed CMM's sample to extend until 1994. However, the Penn World Tables go to great lengths to derive real GDP measures in billions of constant U.S. dollars that ensure comparability across countries, so it provides a viable alternative to the IFS data.

To construct an alternative proxy for country skill abundance, we turn to Barro and Lee data on educational attainment, and define a country's skilled-labor abundance as the average educational attainment. These data run until 1990, so we repeat 1990 values for 1991 and 1992. Our measure of skilled labor contrasts with CMM's use of annual surveys conducted by the International Labour Organization to construct 
measures of skilled labor to total employment by country and year. Specifically, their measure is the percentage of total employment that is employed in categories $0 / 1$ (professional, technical, and kindred workers) and 2 (administrative workers). One concern with their data is comparability of classification schemes across countries (e.g., Japan's share of skilled labor force averages half that of the U.S. and other developed countries). Interestingly, for the observations in the CMM database the correlation between the ILO skill measure and our Barro and Lee education measure is 0.87 .

The variables that provide the largest check on the CMM sample size because of data availability is the trade and investment cost proxies. CMM rely on data from the World Economic Forum (WEF) which provide indicators based on extensive surveys for a limited number of years and countries. For our measure of investment barriers, we use the composite score compiled by Business Environment Risk Intelligence, S.A. (BERI). This composite includes measures of political risk, financial risk, and other economic indicators and ranges between zero and 100, with higher numbers meaning more openness. To compare these estimates to previously used measures of investment barriers, we define Investment Barriers as 100 minus the BERI's composite score. The BERI measure allows us to consider more countries over a longer time period than CMM. There is a strong relation between the two, with a correlation of 0.81 for the observations in the CMM database. As an alternative to the WEF trade cost measures, we use the trade openness measures from the Penn World Tables, which are defined as the sum of a country's imports and exports divided by the countries GDP. We define trade costs as 100 minus this trade openness measure. The correlation between this measure of trade openness and the WEF for overlapping observations is much lower than for the investment cost proxies; only around 0.20 .

The resulting U.S. modified sample, using these alternative proxies for real GDP, skilled labor abundance, and trade and investment costs, covers 51 countries and years from 1983-1992. Appendix Table A1 gives summary statistics for the variables used in the U.S. modified sample.

\section{$\underline{\text { OECD Sample }}$}

Unfortunately, very few OECD countries keep track of affiliate sales, and there is no comprehensive cross-country database of foreign affiliate sales activity, even for OECD countries. Thus, when considering 
the OECD sample, we must resort to data on bilateral FDI stocks as reported by OECD-member countries. These data are reported in the OECD's International Direct Investment Statistics Yearbook. ${ }^{10}$ Since the data are collected from national sources in each country, there is substantial variation in coverage by country source and by year, and there is variation in measurement of FDI activity itself. On the whole, about half of the OECD countries report measures of inward and outward stocks of FDI for some countries and for some years. The earliest data available begin in 1982. Appendix Table A2 provides further details on data coverage across OECD countries and years in our sample. ${ }^{11}$ We converted our FDI variables into thousands of real U.S. dollars using the U.S. GDP deflator as reported in the Economic Report of the President and the yearly average exchange rate as reported by the International Monetary Funds International Financial

\section{Statistics.}

For control regressors, we use the Blonigen-Davies-Head (BDH) alternative proxies described above for the U.S. modified sample. Combining this with the OECD data on FDI outbound stock across countries and time we have a database that spans 15 OECD parent countries, and 38 host countries (some OECD and some non-OECD) over the years 1982 through $1992 .{ }^{12}$ This leaves 2460 observations and Appendix Table A3 provides summary statistics for the variables used in the OECD sample.

\footnotetext{
${ }^{10}$ These data are available in print form in these annual yearbooks or in electronic form on the OECD Statistical Compendium CD-ROM, available for purchase from the OECD.

${ }^{11}$ There are some comparability concerns of FDI measures across countries. For example, a number of OECD countries do not include reinvested earnings by firms in their measures of FDI. Countries can also differ in what percentage of foreign-owned shares of a firm are necessary for it to be classified as FDI rather than portfolio investment. IMF and OECD guidelines specify investment as FDI when acquired shares are ten percent or higher of target firm's outstanding stock, which many of the countries follow or eventually adopted. Graham and Krugman (1993) find that the foreign parent of a MNE in the U.S. on average owns 77.5 percent of the affiliates equity, suggesting that this problem may not be overwhelming. However, with only a couple exceptions, we note that FDI definitions are fairly consistent for the same country over time.

${ }^{12}$ We gathered data on outbound FDI stock only, since most of the reported data on OECD FDI activity is between OECD countries, with some information on FDI stock of OECD countries in non-OECD countries that involve substantial FDI activity. Inbound FDI stock data would only reveal new observations of non-OECD investment into OECD countries, for which there were relatively few instances of such recorded data.
} 
Table A1: Summary Statistics for Modified U.S. Sample.

\begin{tabular}{|l|r|r|r|r|r|}
\hline Variables & \multicolumn{1}{c|}{$\begin{array}{c}\text { Observa- } \\
\text { tions }\end{array}$} & \multicolumn{1}{c|}{ Mean } & \multicolumn{1}{c|}{$\begin{array}{c}\text { Standard } \\
\text { Deviation }\end{array}$} & Minimum & Maximum \\
\hline \hline Real Affiliate Sales & 778 & 20821 & 40630 & 0 & 267401 \\
\hline GDP Sum & 778 & 4523.0 & 484.2 & 3610.2 & 6449.0 \\
\hline GDP Difference Squared & 778 & $1.59 \mathrm{e}+07$ & 3377850 & 5277082 & $2.09 \mathrm{e}+07$ \\
\hline $\begin{array}{l}\text { BDH Skill Difference } \\
\text { (= Educ } \text { - Educ } \text { ) }\end{array}$ & 778 & -0.04 & 5.19 & -9.51 & 9.51 \\
\hline $\begin{array}{l}\text { BDH Skill Difference * GDP } \\
\text { Difference }\end{array}$ & 778 & 18349 & 9687.6 & -6407.9 & 41584 \\
\hline Absolute BDH Skill Difference & 778 & 4.67 & 2.23 & 0.32 & 9.51 \\
\hline $\begin{array}{l}\text { Absolute BDH Skill Difference } \\
* \text { Absolute GDP Difference }\end{array}$ & 778 & 18579 & 9236.9 & 744.3 & 41584 \\
\hline BDH Investment Cost Host & 778 & 37.8 & 13.3 & 17.3 & 70.4 \\
\hline BDH Trade Cost Host & 778 & 58.7 & 44.2 & -278.8 & 91.0 \\
\hline $\begin{array}{l}\text { BDH Trade Cost Host * } \\
\text { Squared Skill Difference }\end{array}$ & 778 & 1723.6 & 1924.8 & -5335.8 & 7337.4 \\
\hline BDH Trade Cost Parent & 778 & 56.0 & 46.1 & -278.8 & 91.0 \\
\hline Distance & 778 & 5077.8 & 2370.8 & 455.0 & 10163.0 \\
\hline
\end{tabular}

NOTES: $\mathrm{p}=$ parent, $\mathrm{h}=$ host. Affiliate sales and FDI stock measured in millions of real U.S. dollars. GDP terms in billions of real U.S. dollars. 
Table A2: Coverage of OECD FDI Stock Data

\begin{tabular}{|l|l|c|c|}
\hline \multirow{2}{*}{ Country } & Direction of FDI Stocks & $\begin{array}{c}\text { Number of Partner } \\
\text { Countries Reported }^{\mathbf{a}}\end{array}$ & Years Covered $^{\mathbf{b}}$ \\
\hline \hline \multirow{2}{*}{ Australia } & Inbound & 17 & $1982-$ \\
& Outbound & 12 & $1982-$ \\
\hline Austria & Inbound & 9 & $1982,1986-$ \\
& Outbound & 11 & $1982,1986-$ \\
\hline Canada & Inbound & 29 & $1982-$ \\
& Outbound & 30 & $1982-$ \\
\hline Finland & Inbound & 1 & $1987-$ \\
\hline France & Inbound & 43 & $1987-$ \\
\hline Italy & Outbound & 34 & $1985-$ \\
& Inbound & 22 & $1985-$ \\
\hline Japan & Outbound & 23 & $1982-$ \\
& Inbound & 9 & $1982-$ \\
\hline Netherlands & Outbound & 37 & $1984-$ \\
\hline Norway & Inbound & 14 & $1987-$ \\
& Outbound & 14 & $1988-$ \\
\hline United Kingdom & Inbound & 24 & $1982-$ \\
& Outbound & 19 & $1984,1987-$ \\
\hline United States & Inbound & 35 & $1982-$ \\
& Outbound & 28 & $1982-$ \\
\hline
\end{tabular}

Notes: Number of partner countries reported are for 1990. Not all reported countries are necessarily reported each year during range indicated. 
Table A3: Summary Statistics for OECD Sample.

\begin{tabular}{|l|r|r|r|r|r|}
\hline Variables & \multicolumn{1}{c|}{$\begin{array}{c}\text { Observa- } \\
\text { tions }\end{array}$} & \multicolumn{1}{c|}{ Mean } & \multicolumn{1}{c|}{$\begin{array}{c}\text { Standard } \\
\text { Deviation }\end{array}$} & Minimum & Maximum \\
\hline Real FDI Stock & 2460 & 4321.5 & 11762 & -357.1 & 176781 \\
\hline GDP Sum & 2460 & 1674.1 & 1497.7 & 73.0 & 6449.0 \\
\hline GDP Difference Squared & 2460 & 3156324 & 5820788 & 0 & $2.09 \mathrm{e}+07$ \\
\hline $\begin{array}{l}\text { BDH Skill Difference } \\
\text { (= Educ } \text { - Educ } \text { ) }\end{array}$ & 2460 & 1.65 & 2.69 & -5.40 & 8.10 \\
\hline $\begin{array}{l}\text { BDH Skill Difference * GDP } \\
\text { Difference }\end{array}$ & 2460 & 3401.2 & 6459.6 & -6995.7 & 31011 \\
\hline Absolute BDH Skill Difference & 2460 & 2.55 & 1.86 & 0.01 & 8.10 \\
\hline $\begin{array}{l}\text { Absolute BDH Skill Difference } \\
* \text { Absolute GDP Difference }\end{array}$ & 2460 & 3850.4 & 6202.3 & 0.03 & 31011 \\
\hline BDH Investment Cost Host & 2460 & 42.0 & 12.3 & 17.3 & 65.0 \\
\hline BDH Trade Cost Host & 2460 & 31.3 & 59.3 & -286.2 & 87.3 \\
\hline $\begin{array}{l}\text { BDH Trade Cost Host * } \\
\text { Squared Skill Difference }\end{array}$ & 2460 & 422.6 & 1050.1 & -6559.1 & 5599.5 \\
\hline BDH Trade Cost Parent & 2460 & 52.0 & 22.3 & -18.8 & 82.04 \\
\hline Distance & 2460 & 6302.6 & 4791.6 & 174.0 & 18372 \\
\hline
\end{tabular}

NOTES: $\mathrm{p}=$ parent, $\mathrm{h}=$ host. Affiliates sales and FDI stock measured in millions of real U.S. dollars. GDP terms in billions of real U.S. dollars. 